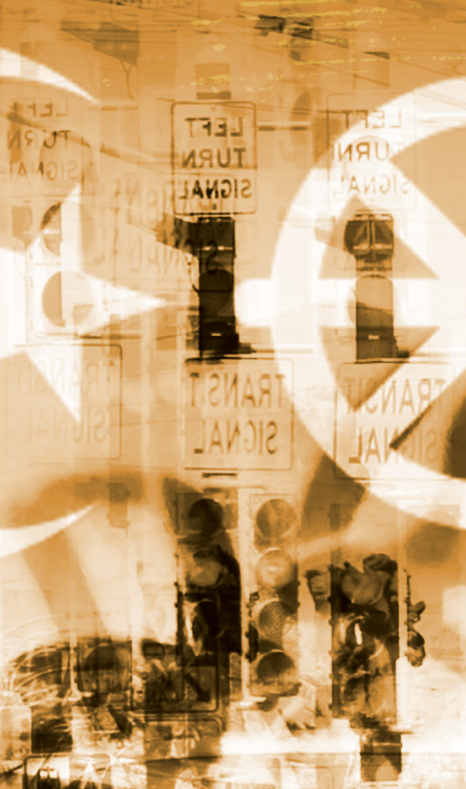

and of

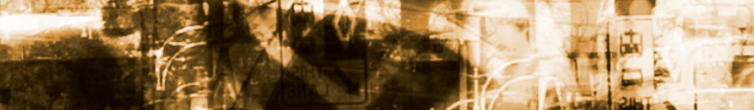

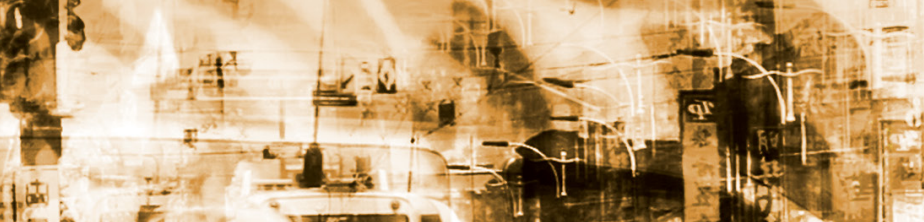
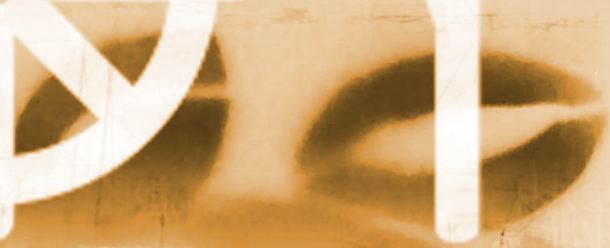

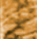

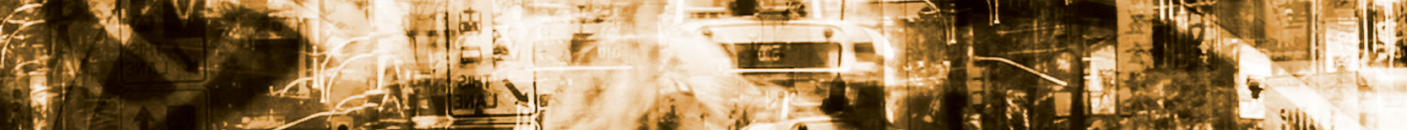

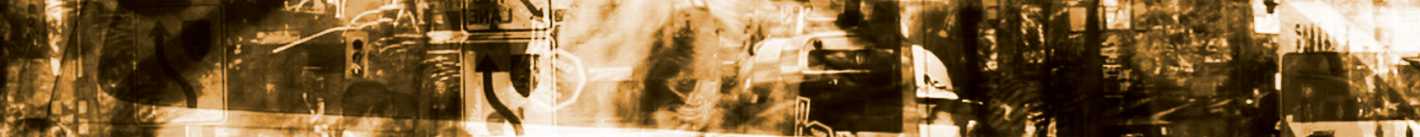

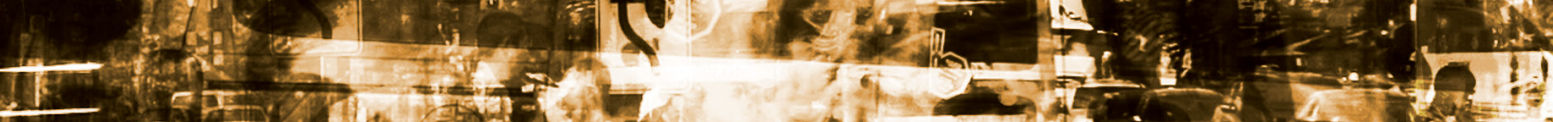

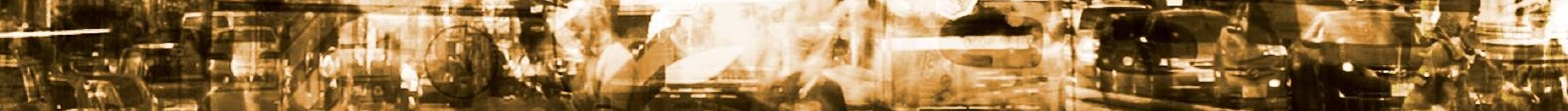
1.

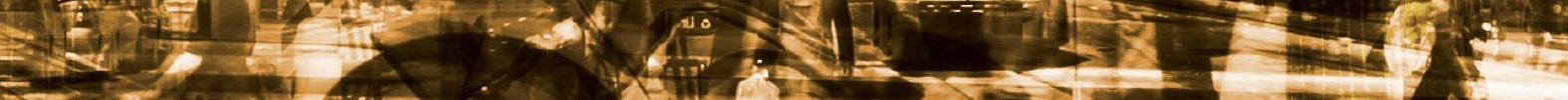

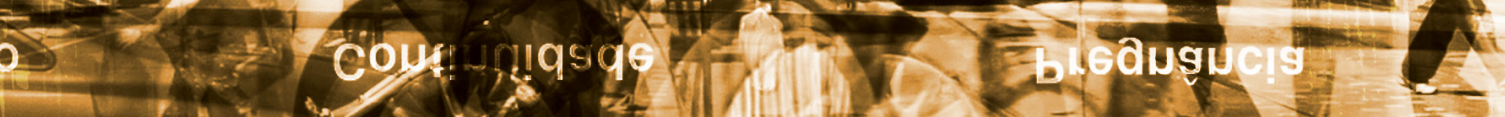

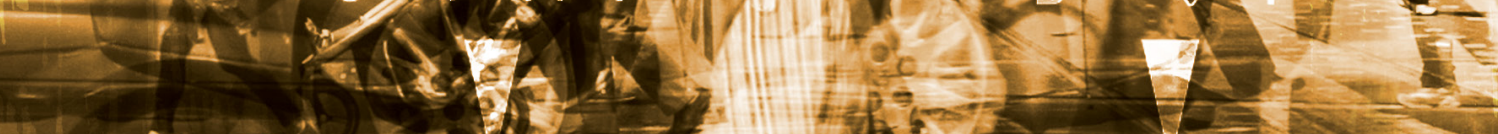

act 20 a Hit $=t^{2}$

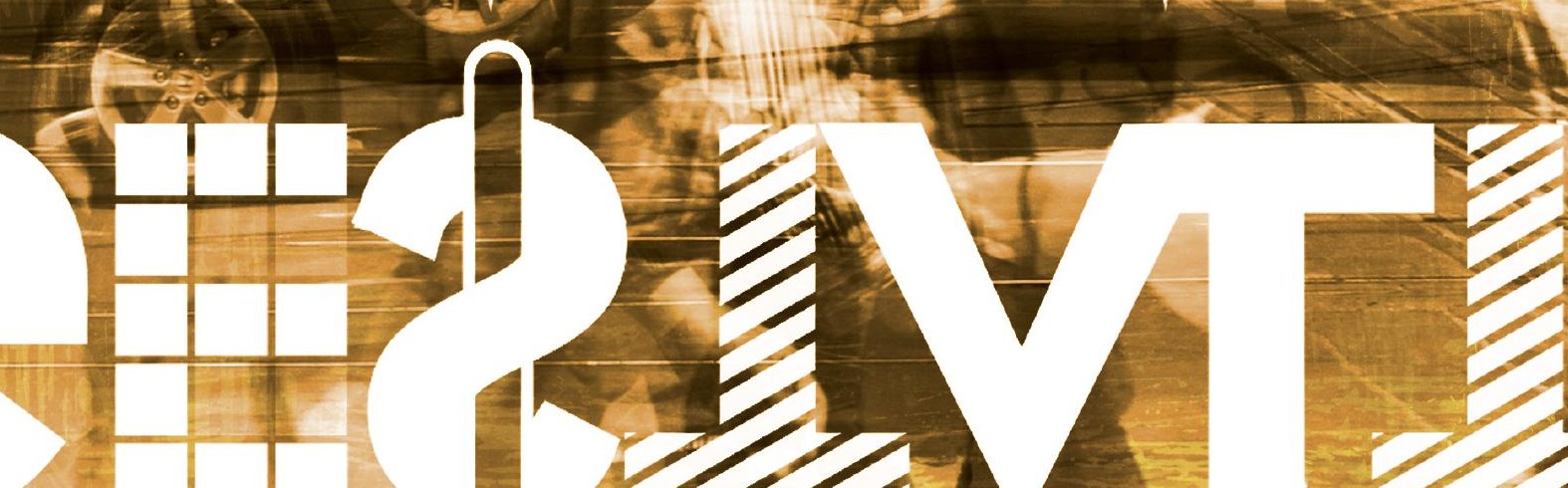




\section{ABRIL, Gonzalo (2013): Cultura visual, de la semiótica a la política. Plaza y Valdés Editores: Madrid, 228 páginas.}

DOI: $10.15213 /$ REDES.N12.P410

PABLO MARTÍNEZ COUSINOU

En el largo recorrido que va desde las primeras aproximaciones al estudio de los modos de representación del método iconológico de Aby Warburg a la actual semiótica visual, la historia cultural de la representación nos muestra que la pregunta por el significado complejo de las imágenes pasa por una reflexión sobre la relación de éstas con el poder, los imaginarios construidos y la política.

En esta nueva publicación, el profesor Gonzalo Abril nos ofrece un recorrido de indagación por los procesos de producción de sentido de los textos visuales que va desde una inicial propuesta metodológica de análisis semiótico, a un cuestionamiento por el significado político de los imaginarios que conforman los textos visuales en la actual era del mundo-imagen, como cita el propio autor parafraseando a Buck-Morss (1995).

La obra se presenta estructurada en dos bloques, "Textos y culturas visuales" y "Escenarios políticos de la imagen”, que responden a un afán por revitalizar la perspectiva crítica aplicada a la lectura de la producción visual desde una interpretación compleja y contextualizada. Un recorrido que incide en una traslación de la reflexión desde el interés por la imagen óptica, lo visible concreto y sensible, a la imagen escópica, la que se pregunta por el enunciado de la mirada que se construye en relación con el tejido de la visibilidad público-política; una incursión en el estimulante terreno de los discursos visuales en su amplia paleta de prácticas sociodiscursivas.

En el primer bloque, Gonzalo Abril desarrolla una propuesta de interpretación de las imágenes a partir de lo que denomina las "tres dimensiones de los textos visuales", a saber, la visualidad, la mirada y la imagen. La visualidad, nos dice el autor, hace referencia a la visión, a la percepción fisiológica, a la que hay que sumar la "visión socializada", es decir, aquella que incorpora la "mochila" de experiencias y condicionantes que conforman nuestra visión singular como espectadores.

La mirada hace referencia, por un lado, a la perspectiva desde la que se crea el texto visual, perspectiva entendida en sentido amplio, perspectiva cultural, así como al lugar que se ofrece al espectador en la representación. La mirada está en este sentido conectada con las relaciones de poder que se establecen en la representación, con el lugar de enunciación elegido. El 
tercer elemento, la imagen, según Abril, sería entendida como imaginario. El significado de una imagen no se agota en lo visible, sino que alberga también lo invisible. Las imágenes están vinculadas a imaginarios sociales, son parte y resultado de los imaginarios.

Esta propuesta de las tres dimensiones de los textos visuales, presentadas a su vez como ámbitos porosos, no estancos, abiertos e interconectados por una relación de continuidad y de dependencia recíproca, bebe de la tradición semiótica, representando en cierto sentido, un aggiornamento de los tres niveles del método iconológico de Panofsky (pre-iconógráfico, iconográfico e iconológico) por un lado, así como de la propuesta igualmente triangular de análisis de imagen de Roland Barthes basada en "lo obvio", "lo obtuso" y "la significancia”.

En el discurrir de lo objetivable a lo interpretable que es en gran medida todo análisis semiótico, Abril recupera y revitaliza, como citábamos, la idea de imaginario, vínculo de conexión con el carácter político inherente a toda representación. A partir de aquí desarrolla el segundo bloque en el que se pregunta por la evolución de las imágenes mediáticas y su relación con la política.

En primer lugar, el autor se detiene en un análisis del surrealismo y de su paradójica coalescencia con el imaginario del capitalismo. Más allá de la ruptura del espejo que supusieron las vanguardias, la fragmentación de los objetos desarrollada por el surrealismo encontró en la publicidad y en el desarrollo de las tecnologías del deseo derivadas de ésta una continuidad extraordinaria; la fragmentación surrealista no distaría del fetichismo de la mercancía propio del capitalismo de consumo y de la cultura de masas, nos dice Abril. Su inicial afán transgresor y transformador quedó subsumido en el ámbito del discurso publicitario y, de este modo, desarticulado su mensaje crítico inicial. En el encuentro que como citaba Benjamin (1936) se va a dar entre "la estetización de la política" que llevarán a cabo los fascismos y la "politización del arte" que proponía Bertolt Brecht como contestación a aquellas, se definirán las líneas maestras del posterior desarrollo espectacular del imaginario y configuración escénica de la esfera política.

En un segundo capítulo, Abril se ocupa de la relación entre el orden político y los regímenes de visión inherentes a ellos, las regulaciones implícitas en lo que públicamente se legitima como visible frente a lo que se invisibiliza, su relación con el espacio público-político. Subraya la importancia de las imágenes en la conformación de imaginarios que históricamente han estado vinculados a la existencia y mantenimiento de un determinado status quo. El autor recurre nuevamente a Buck-Morss (2005) para visibilizar esta 
conexión "imaginario sociocultural-orden social" a partir del análisis de la producción y difusión de imágenes, para preguntarse por el imaginario alimentado de lo público y del espacio común. La pregunta política subyacente aflora aquí nuevamente evidenciando las conexiones entre ideología y representación. El orden subversivo inicial del surrealismo vinculado al deseo es recuperado para hablar de la erotización de la política en el desarrollo de la propaganda visual. Critica el autor de este modo la deriva experimentada por las imágenes mediáticas desde su finalidad informativa hacia un uso y estética expresivos, una tendencia a la espectacularización estandarizada en la televisión que se fue extendiendo progresivamente a la imagen en prensa.

Abril describe así el contexto presente en el que frente a un aparente descrédito de las palabras, la expresividad simbólica y emocional de las imágenes, acentuada por la estetización de su contenido, ha ocupado el espacio central del ámbito político, relegando el debate de ideas a un ámbito prácticamente inexistente a nivel mediático.

En el marco de los estudios visuales, esta aportación del profesor Abril al estudio de la imagen como práctica de significación se nos muestra de máxima actualidad, al subrayar el carácter político y por ende ideológico de toda representación así como la necesidad de participar activamente en la construcción y difusión de imaginarios alternativos, como respuesta al aparente único modelo cosmogónico que domina en la iconosfera mediática contemporánea. El debate queda abierto: se hace perentorio comprender, desde el ámbito discursivo de la imagen, la importancia de la disputa por el sentido común como espacio de combate político y la posibilidad de empoderamiento de la población a partir de su participación activa en la producción de significado social: "En tanto que históricos, -cita Abril- los imaginarios sociales son también territorios de pugna por el control del sentido, por el uso social y político de los símbolos".

Cultura visual, de la semiótica a la política es así un texto generoso y comprometido que nos invita a participar del afán por la emancipación y a recuperar, en la actual era del Capitalismo Cognitivo "una ciencia social crítica" - añadiríamos, y pragmática-, que nos ayude a una mejor comprensión y participación en nuestro presente. 